Histoire Épistémologie Langage

\section{Histoire Épistémologie Langage}

42-1 | 2020

La grammaire arabe étendue

\title{
Extended grammar: Malay and the Arabic tradition
}

\section{Kees Versteegh}

\section{(2) OpenEdition}

\section{Journals}

Electronic version

URL: https://journals.openedition.org/hel/462

DOI: $10.4000 /$ hel.462

ISSN: $1638-1580$

\section{Publisher}

Société d'histoire et d'épistémologie des sciences du langage

\section{Printed version}

Date of publication: 28 September 2020

Number of pages: 13-31

ISSN: 0750-8069

\section{Electronic reference}

Kees Versteegh, "Extended grammar: Malay and the Arabic tradition", Histoire Épistémologie Langage

[Online], 42-1 | 2020, Online since 28 October 2021, connection on 29 October 2021. URL: http:// journals.openedition.org/hel/462 ; DOI: https://doi.org/10.4000/hel.462

This text was automatically generated on 29 October 2021.

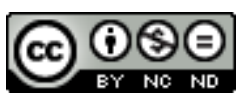

HEL is licensed under a Creative Commons Attribution-NonCommercial-NoDerivatives 4.0 International License 


\title{
Extended grammar: Malay and the Arabic tradition
}

\author{
Kees Versteegh
}

\section{Learning a learned language}

1 The reasons for choosing a learned language and the mechanisms by which this learned language becomes entrenched in an educational system have been studied extensively, for instance by Ostler (2005) and Hamel (2005). ${ }^{1}$ Learned languages may be useful for any number of religious, political, or scholarly reasons, but are typically not used for everyday communication. Historical examples include Sumerian in Akkad, Latin in Medieval Europe, Greek in Classical Rome and in the Hellenistic world, Sanskrit in Southeast Asia, Chinese in East Asia, Persian in the Mughal and Ottoman empires, and Arabic in large parts of the Islamic world.

2 Those who know a learned language become members of an elite, who can afford to send their children to the right schools where the learned language occupies a central place. For practical reasons, a vernacular language often serves as the medium of instruction. In the Arabic-speaking world, for instance, Berber was used in schools in the Sous region as a language of instruction for beginning students. Referring to the Qur'ānic verse (Q.14/4) that God has sent messengers to each community in their own language, the Berber poet Muhammad Aznag (16th century CE) expresses this as follows: "Arabic is the language of the Seal of the Prophets/A Berber will understand it in Berber" (l'arabi lluga $n$ Hुātimu lanbiyya/yan igan amazig̈ ifhm $t s$ lmazgìy-i) (van den Boogert 1997: 49).

3 Teaching a learned language takes place largely on the basis of texts, which are memorized together with their translation in the vernacular language. The translation is often word-by-word, creating a linguistic variety that Riddell (2002) calls "translationese". Eickelman (1978) has analyzed how such a system of learning affects the selection of texts and the establishment of a canon in all disciplines, including 
grammar. For most students, linguistic knowledge was determined by a few grammatical treatises learnt by heart together with their translation.

The translating tradition created a stock of technical terms in the vernacular language. The teaching of Latin in the abbey of Saint Gall, for instance, took place with Old High German as an auxiliary language. As a result, a host of old High German loan translations of Latin terms entered the language (Grotans 2006). In other cases, the Latin terminology was taken over wholesale in the form of loanwords. In the Irish tradition, two sets of terminology were used, one with mostly Irish loan translations, intended for an audience of students and learners, the other with mostly Latin loanwords, used by scholars (Poppe 1999). In much of the Islamic world, the Arabic tradition was followed faithfully and its technical lexicon predominated, so that Arabic loanwords constituted the bulk of new technical terminology, with only a relatively small number of loan translations, as in Persian and Turkic grammar. In this respect, the Malay tradition was an exception, since, along with Arabic loanwords, it frequently used loan translations.

The coexistence of two languages in education is likely to provoke a comparison of their structure and qualities. The vernacular language is usually seen as a poorer variety, more lively, perhaps, and better suited to the expression of feelings, but not as rich or rational as the learned language, and certainly not deserving a grammatical analysis of its own. Most people speak the vernacular language as their mother tongue anyway and do not feel the need for a grammar. Yet, in some cases, scholars took the initiative to write a grammar of their vernacular language, for which they depended on the grammatical framework of the learned language. In Europe, Latin, the language in which all religious and scientific literature was written (Waquet 1998), provided the framework for all grammar study. The universality of its structure was taken for granted, even when people were aware of the differences with their own vernacular.

The full emancipation of the vernacular language became possible only when the sociopolitical context changed. In Europe, the triggering factor was the establishment of political entities that focused on their identity as a nation with a language of its own. After the Reconquista had been completed, the Spanish kings strove at founding an empire with one ruler, one religion, and one language. The publication of Nebrija's grammar of Castilian in 1492, the first of its kind in Europe, showed that this new imperial language was just as capable of expressing anything as the prestige language, Latin. Nonetheless, the linguistic framework in which this newly emancipated language was described remained the Latin one.

7 In the Arabic-speaking world, too, vernacular languages were generally seen as inferior to Arabic and not deserving a grammar of their own. Exceptions to this view are few and far between. In a discussion about the Syriac language that took place in 364/1026 between the Christian bishop Elias of Nisibis and the vizier 'Abū l-Qāsim al-Ḥusayn ibn 'Alī, the Syrian bishop vigorously defended the superior quality of the Syriac language (Bertaina 2011): Not only is it possible to say in Syriac whatever you can say in Arabic, but it is even superior. When Elias is asked by the vizier whether Syriac distinguishes between the agent and the object by means of case endings ('i'rāb), he explains that in Syriac a particle, $l-$, is used for the object, at least in those cases where confusion is possible. This is much better than the Arabic system, he says, which breaks down in words with virtual endings, like daraba 'îsa $m \bar{a} s \bar{a}$ " IIsā hit Mūsā'. Elias states that the ' $i$ 'rāb fails in its main function, i.e. removing ambiguity (labs, iltibās), not only 
between $f \bar{a}^{\prime} i l$ (agent) and maf' $\bar{u} l$ (object), but also between sentence types, such as assertion and question (Majāis: 116-118). In spoken Arabic and Syriac, such distinctions are expressed by intonation (nagamäăt al-șawt; ibid.: 113.8), but while in written Arabic there is no way to indicate them, Syriac scholars have devised a system of interpunction ('alāmāt) for this purpose (ibid.: 122).

The pride Elias takes in the Syriac language may have had something to do with the fact that before the emergence of the Arabic tradition Syriac possessed a grammatical tradition of its own. In other cases, language communities developed their own tradition in Islamic times. The revival of Coptic and the emergence of Coptic grammars in the thirteenth century $\mathrm{CE}$, for instance, came at a time of social and cultural emancipation of the Copts, when Coptic scholars aimed to demonstrate the rich texture of their language (Sidarus 2010). A similar apologetic aim is found in the dictionary of the Turkic languages by al-Kāšgarī (11th century CE). In his Diwwān luġāt al-Turk, he intended to show that the Turkic languages were just as capable as Arabic to express complex thoughts, with an equally rich lexicon (Ermers 1999: 17).

While Syriac could not qualify for 'i'rābhood because it does not have endings, some languages do have declensional endings. In Persian, the direct object suffix -rā was interpreted by Persian grammarians as a harf-i taHșịs 'particle of specification', until later grammarians named it 'alāmat-i maf' 'ūl 'marker of the object' (Jeremiás 1997: 174 $\& 180$, n. 20). In Turkic, the ending $-n \bar{i}$ of the direct object was called by some grammarians 'alämat al-nașb 'marker of the accusative' (Ermers 1999: 163-284). The Persian and Turkic endings received the Arabic name of the function they expressed (nașb, maf' $\bar{u} l$ ), but were not analyzed as instances of ' $i$ 'rāb: they expressed the same syntactic categories as the ones marked by 'i'rāb in Arabic, but used different tools to mark them. This approach parallels the description of European vernacular languages within a Latin framework: their lack of declensional endings was compensated by applying Latin case names to the syntactic functions of words.

Since the pioneers who started to focus on the vernacular language had been trained in the powerful linguistic model of the learned grammatical tradition, which had the status of a universal grammar, valid for all languages, they had to find a way to accommodate the structure of their own language to this model. In the next section, we shall see how this played out in the description of Malay in Southeast Asia.

\section{Malay as an auxiliary language}

11 Arabic was introduced in Southeast Asia in the wake of Islamization through the thirteenth-fifteenth centuries CE as the written language of the Qur'ān and the Islamic sciences. The language of instruction in the educational system was Malay, the lingua franca of the Malaccan peninsula and the Indonesian islands, for which Arabic script (Jawi) was introduced. Arabic texts were memorized, supported by Malay translations. Grammar as a topic in the schools focused on Arabic, while there was no formal teaching of Malay. During the colonial period from the seventeenth century CE onward, Malay was the language of choice of the British and Dutch administrators, who used it for communication with the indigenous population. They were the first to write grammars of the language for the purpose of training colonial officers, within a Western linguistic framework and terminology (Kaptein 2000). 

their own language, they did not employ the colonial model, but that of Arabic grammar, which until then had been used in Southeast Asia exclusively for the study of Arabic. Yet, since the teaching method in all Islamic disciplines, including grammar and Qur'ānic exegesis, was based on Malay translations, an indigenous Malay terminology had gradually been developed (Riddell 2017). Thus, when these pioneers started to write a grammar of their own language, they did not need to develop all of its terminology from scratch, but could draw on an existing stock of Malay terms (Versteegh 2019).

13 The first and foremost Malay-written grammar of Malay was that of Raja Ali Haji (probably d. 1873), a scholar from the Sultanate of Johor-Riau. At the sultan's court, a form of Classical Malay had become the cultural language shared by courtiers and Dutch colonial administrators alike. In his Bustān al-kātibin [Garden of writers] (1857), Raja Ali Haji provides a grammatical analysis of this Malay, ${ }^{2}$ while his incomplete dictionary Kitab pengetahuan bahasa [Book of the knowledge of the language], written in the 1850s, aims at exploring the lexicon of the language. It opens with a compendium of Arabic grammar (Pengetahuan: 1-27) and features a large number of Arabic grammatical terms (van der Putten 2002).

One of the factors motivating Raja Ali Haji to engage in this project was the deficient performance of many speakers, for whom Malay was a second language, used for interlanguage contact and for dealing with the colonial administration. He explains that many people make mistakes while writing Malay:

I have met many people, either Malays from Johor, or other Malays, not to mention people from other nations, who did not have Malay as their own language and whose faulty practice even reached the point where they started to teach each other, while believing themselves to be experts in this science (Telah banyaklah aku dapat orang Melayu Johor atau Melayu yang lainnya, apalagi orang yang lain-lain bangsa daripada bangsa yang bukan bahasa Melayu itu bahasa dirinya, hingga berpanjanganlah amalnya yang palsu itu hingga mengajarlah setengahnya akan setengahnya padahal ia menyangkakan akan dirinya ahli pada ilmu itu; Bustān: 6).

This is a recurrent theme in his treatise: as people make mistakes in writing or speaking Malay, their work becomes worthless. What is worse, they are not even aware of the fact that their Malay is faulty. Since a number of letters of the Arabic alphabet are not used in spoken Malay, people err by adding or omitting letters (ibid.: 13), or by writing the wrong ligatures (ibid: 14). This shows that they possess only "stolen knowledge" (ilmu yang dapat dicurinya; ibid.: 14.18f.). The concluding chapter of the treatise (ibid.: 48-51) touches upon yet another aspect of the author's didactic ambition in writing his grammar. It is dedicated to the art of epistolography and includes precise instructions on the proper way to address people of different rank, urging the reader to use a polite style of Malay (ibid.: 49).

Like the Coptic, Turkic, and Syriac grammarians, Raja Ali Haji describes his own language on the premiss that anything said in Arabic can also be said in Malay. Both languages share an underlying structure that is identical with the model of the Arabic grammarians. He does not aim at a full-scale grammatical description of the Malay language, but only at a short instruction for those wishing to improve the quality of their writing and speaking. Yet, some rules are necessary:

Nonetheless I have, where necessary, borrowed explanations, analogies, and methods from the science of the Arabs, such as sarf 'morphology', nahw 'syntax',

Histoire Épistémologie Langage, 42-1 | 2020 
luga 'lexicography' and others from the scientific literature, to compose this book... (Syahadan sungguhpun yang demikian itu tempatnya aku mengambil petua dan kias dan jalan memperbuat kitab ini, iaitu ilmu Arab juga seperti șarf dan naḥw dan luġa dan lainnya daripada kitab ilmu...; Bustān: 24.33-25.1).

And, indeed, he freely uses Arabic grammatical terminology and, in some sections, snippets of linguistic theory taken from the Arabic grammatical literature. The main source for his description is the 'Ājurrūmiyya and its commentaries, ${ }^{3}$ as is clear from the parallels in treatment. In addition, he must have been familiar with the 'Alfiyya tradition. Since the elementary grammatical treatises and commentaries are highly interdependent, it is not always possible to pinpoint the exact source. Viain's (2014) detailed comparison of the structure of the 'Alfiyya (2014: 228-253, 504-508) and the 'Ájurrūmiyya (2014: 254-259, 509-511) points out the following differences between them:

i. Both texts have a rough division into nouns and verbs, but the 'Ājurrūmiyya first treats general rules of 'i'rāb, while the 'Alfiyya first deals with a number of other constructions (relatives, numerals, hikāya).

ii. The 'Ájurrümiyya starts with the verb, the 'Alfiyya with the noun; for the noun, both traditions follow a division into marfü' āt, manșūbāt, maHfūạāt.

iii. Within the nominative constructions, the 'Äjurrūmiyya starts with the fā' $i l$, the 'Alfiyya with the mubtada'.

iv. Within the accusative constructions, the 'Äjurrümiyya begins with the maf' ūl bihi, followed by the maf'ūl muttlaq, while the 'Alfiyya has the reverse order.

v. Within the satellite constructions, the order in the 'Äjurrūmiyya is $n a^{\prime} t$ - ta'kid - 'atf badal; in the 'Alfiyya tradition ta' kid and 'at f switch places.

18 A look at the chapters of the Bustān (Table 1) shows that sometimes their order reflects that of the 'Ajjurrümiyya, for instance by treating first the maf' $\bar{u} l$ bihi and then the maf' $\bar{u} l$ mutlaq, but at other times it follows more closely that of the 'Alfiyya tradition, for instance in treating the noun before the verb, and the mubtada' before the fá $'$ il. Within the chapters, the relationship with the 'Äjurrūmiyya commentaries is evident, yet it appears that the author inserted remarks from an amalgam of different traditions. Obviously, as a nineteenth-century Muslim intellectual he must have been familiar with commentaries from both traditions.

Table 1. Chapters of the Bustān

\begin{tabular}{|l|l|l|}
\hline & introduction & p. 3-11 \\
\hline$\S 1$ & letters & p. 12 \\
\hline$\S 2$ & alphabet & p. 12 f. \\
\hline$\S 3$ & Jawi spelling & p. 13 \\
\hline$\S \S 4-9$ & orthography & p. $13-25$ \\
\hline$\S 10$ & parts of speech & p. 25f. \\
\hline$\S 11$ & ism & p. 26-29 \\
\hline
\end{tabular}




\begin{tabular}{|c|c|c|}
\hline$\S 12$ & $\mathrm{fi}^{\mathrm{C}} \mathrm{l}$ & p. 29-32 \\
\hline$\S 13$ & harf & p. $32-38$ \\
\hline$\S 14$ & kalām/kalima & p. 38f. \\
\hline$\S 15$ & mubtada'/Habar & p. $39-42$ \\
\hline$\S 16$ & types of sentence & p. 42 \\
\hline$\$ 17$ & $f_{i}{ }^{\prime} l / f \bar{a}{ }^{\prime} i l$ & p. $42 f$. \\
\hline$\S 18$ & $m a f^{x} \bar{u} l$ bihi & p. 43 \\
\hline$\S 19$ & maf'ūl muțlaq & p. $43 \mathrm{f}$. \\
\hline$\S 20$ & maf' $\bar{u} l$ lahu & p. 44 \\
\hline$\S 21$ & maf' ūl fihi & p. 44 \\
\hline$\S 22$ & $m a f^{r} \bar{u} l m a^{\prime} a h u$ & p. 44 \\
\hline$\S 23$ & $h \bar{a} \bar{l}$ & p. $44 \mathrm{f}$. \\
\hline$\S 24$ & tamyizz & p. 45 \\
\hline$\S 25$ & $t a^{\prime} k i d$ & p. 45 \\
\hline$\S 26$ & badal & p. $45 \mathrm{f}$. \\
\hline$\S 27$ & șifa & p. 46 \\
\hline$\S 28$ & 'iḍāfa & p. 47 \\
\hline \multirow[t]{2}{*}{$\S 29-30$} & epistolography & p. $47-51$ \\
\hline & epilogue & p. $51-53$ \\
\hline
\end{tabular}

19 There is one aspect in which Raja Ali Haji's work differs from the commentaries in the Arabic tradition: his preoccupation with spelling and orthography. Spelling rules did not form part of Arabic grammar, but were crucial in Southeast Asia because of the idiosyncrasies of the Jawi script. Raja Ali Haji's discussion of 'i'rāb (Bustān: 20f.) starts with the observation that it consists of a stroke (baris) above or underneath the letter, indicating a vowel, in combination with a letter $w \bar{a} w, y \bar{a}$ ', or 'alif. This clearly addresses the representation of vowels in Jawi script, rather than declension, which is inexistent in Malay. But then, confusingly, he continues by defining 'i'rāb as "changes in the endings of speech due to the difference in governing words, overt or implicit" ( $m \bar{a}$ taġayyara 'awāHir al-kalām li-Htilāe al-'awāmil al-dāHila 'alayhā lafžan 'aw taqdīran; ibid.: 20.14f.). ${ }^{4}$ However, he says, the rules of ' $i$ ' $r a \bar{b} b$ are very difficult and "it is not my purpose to translate the 'ilm al-nahw, but only to set up rules for writing and speaking Malay" (bukan maksudku hendak menterjemahkan ilmu nahu, hanyalah maksudku hendak mengatur 
peraturan tertib surat-suratan dan perkataan bahasa Melayu juga; ibid:: 24.29-31). Therefore, he returns to the rules for correctly spelling the vowels in Malay, which are dealt with in the first nine sections of his treatise after the introduction (ibid.: 12-25). The main problem is that in Jawi script vowels are sometimes marked with and sometimes without a glide consonant. A word like kepada 'for' is spelt correctly $<\mathrm{kpd}>$, but di dalam 'within' is spelt $<\mathrm{dd}$ 'lam>. According to Raja Ali Haji, people without an education are confused by this orthography and do not grasp the underlying rules (ibid:: 21). The main rule, he says, is that in words that are free from ambiguity, there is no need for any additional letters to indicate the pronunciation: $<\mathrm{drpd}>$ is immediately recognized as daripada 'from', so there is no need for clarification. But in words like kota 'city', kata 'word', kita 'we [incl.]', writing the glide $<\mathrm{k}$ ' $\mathrm{t}>,<\mathrm{kwt}>$, and $<\mathrm{kyt}>$ is necessary in order to distinguish them from each other (ibid.: 23). ${ }^{5}$

It is not clear whether Raja Ali Haji regards Arabic as a superior language. He seems to believe firmly in the richness of his own language, at least for those who know how to speak it well. Occasionally, however, he refers to a qualitative difference in the linguistic inventory, for instance with respect to the negations. After explaining that the Malay negation tiada is used for both generic and specific negations, he remarks:

Malay is extremely poor compared to Arabic. In Arabic there are two, three, four different negative particles, each with its own rules (Sangatlah miskinnya bahasa Melayu ini jika dibangsakan dengan bahasa 'Arab. Adapun pada bahasa 'Arab harf tiada itu ada dua, tiga, empat jenis, masing-masing dengan hukumnya; ibid.: 35.23-26).

Differences between the two languages are noted throughout the Bustān, for instance in the verbal system. Raja Ali Haji explains that there are three classes of verbs, fi' māa $\bar{d} \bar{i}$ (perfect), fi'l mudāri' (imperfect), and fi'l 'amr (imperative). In Arabic, these three classes have different forms, but in Malay, the same meanings can be expressed by adding a particle (ibid.: 30.2f.): "As the sign of the fi'l mādi telah may be used, e.g. telah memukul "he hit"' (Adapun tanda fi'l mādì itu, boleh ditanggungkan telah seperti telah memukul). The term tanda is used here as an equivalent of 'alāma 'sign, marker', which occurs elsewhere. Likewise, the fi'l mudāri' is expressed by adding lagi akan, e.g. lagi akan memukul 'he'll hit' (ibid.: 31.7).

Another example occurs in the discussion about those particles that govern the genitive (jarr), where it is stated explicitly that the two languages express the same meaning with different syntactic means:

When this particle occurs in Arabic, it needs its majrür [i.e. genitive] which is governed by it. ${ }^{6}$ In Malay there is no mention of its majüru, only of its intention and its meaning (Jika pada bahasa 'Arab datang harf itu berkehendaklah majrürnya yang dikhabarkannya. Jika pada bahasa Melayu tiadalah dibicarakan majrūrnya itu melainkan kehendaknya dan maknanya jua, adanya; ibid.: 32.12-15). ${ }^{7}$

In the next section, we shall follow the order of the chapters of the Bustān to see how Raja Ali Haji extends the rules of Arabic grammar to Malay.

\section{Arabic grammar extended to Malay}

Raja Ali Haji's indebtedness to the Arabic grammatical tradition is evident right away from his classification of the parts of speech, in which he follows the Arabic tripartition: 
Speech that is produced has to be one of three things. The first is in Arabic ism, which means 'name', the second is fi'l, which means 'action', and the third harf. By this we mean here the harf that has a meaning ${ }^{8}$ (Bermula yang diperbuat perkataannya itu tiadalah sunyi ia daripada tiga perkara. Pertama, pada bahasa 'Arab ism yakni nama, dan kedua, fi'l yakni perbuatan, dan ketiga harf. Maka dikehendak harf di sini harf yang ada baginya makna; ibid.: 25f.).

After having introduced the three parts of speech with their Arabic names and the Malay equivalent for the noun (nama) and the verb (perbuatan), Raja Ali Haji deals with each part in a separate section under its Arabic name (ism, ibid.: 26-29; fi'l, ibid.: 29-32; harf, ibid.: 32-38). The order of treatment, first the noun, then the verb, follows that of the 'Alfiyya, as the 'Ājurrūmiyya begins with the verb.

Within the sections about the noun and the verb, the pattern of the 'Ajurrümiyya is followed more or less closely. For the nouns, the division into indefinite (nakira) and definite ( $m a^{\text {' } r i f a) ~ n o u n s ~}{ }^{9}$ follows right after the classification of the parts of speech (ibid.: 26-29). The definite nouns are divided into five categories, damir (personal pronoun), 'alam (proper noun), 'išāra (demonstrative), mawșūl (relative), 'iḍāfa (annexion), omitting the noun with the definite article, but splitting the category of mubham (a generic term for demonstrative and relative pronouns) of the 'Ājurrūmiyya into demonstratives and relatives. ${ }^{10}$

For the analysis of the verbal forms in Malay, we need to go to the Kitab pengetahuan bahasa. According to van der Putten (2002: 426), two verbal forms are analyzed by Raja Ali Haji as nominals: the meN-form, which focuses on the agent, is called ism fā'il and translated as orang yang... 'someone who...', whereas the di-form, which focuses on the patient, is called ism maf' $\bar{u}$ l and translated as orang yang kena... 'someone who is affected by...'. A typical example is found in the lemma ubat (obat) 'medicine' (Pengetahuan: 87f.), with its derived forms (Table 2). The term ism fi ${ }^{\prime} l$ is used to indicate the root word ubat, which can only be used nominally. ${ }^{11}$ While the explanation of the derived forms does not impose a nominal interpretation per se, the terminology used in classifying them does not seem to leave room for any alternative interpretation.

Table 2. The lemma ubat in the Pengetahuan: $87 f$.

\begin{tabular}{|c|c|c|}
\hline $\begin{array}{l}\text { ubat } \\
\text { 'medicine' }\end{array}$ & [explanation of what a medicine is] & ism fi'l \\
\hline $\begin{array}{l}\text { mengubat } \\
\text { 'to heal' }\end{array}$ & $\begin{array}{l}\text { "i.e., someone who heals someone" (iaitu orang yang mengubatkan } \\
\text { orang) }\end{array}$ & ism fā'il \\
\hline $\begin{array}{l}\text { diubatkan } \\
\text { 'to be treated' }\end{array}$ & $\begin{array}{l}\text { "i.e. someone who has undergone treatment" (iaitu orang yang kena } \\
\text { ubat) }\end{array}$ & ism maf' $\bar{u} l$ \\
\hline $\begin{array}{l}\text { berubat } \\
\text { 'to take a } \\
\text { medicine' }\end{array}$ & $\begin{array}{l}\text { "i.e., someone who has fallen ill takes a medicine" (iaitu orang yang } \\
\text { kena penyakit berubat ia) }\end{array}$ & $h \bar{a} \bar{l}$ \\
\hline $\begin{array}{l}\text { ubatkanlah } \\
\text { 'heal!' }\end{array}$ & $\begin{array}{l}\text { "i.e., someone orders someone to treat a patient" (iaitu seseorang } \\
\text { menyuruh kepada seseorang mengubatkan penyakit) }\end{array}$ & fi'l'amr \\
\hline
\end{tabular}




\begin{tabular}{|l|l|l|}
\hline $\begin{array}{l}\text { perubatan } \\
\text { 'taking } \\
\text { medicine' }\end{array}$ & $\begin{array}{l}\text { “i.e., people are discussing the act of taking medicine” (iaitu orang yang } \\
\text { berkhabar-khabar akan pekerjaan berubat-ubatan) }\end{array}$ & $\begin{array}{l}\text { ta'wĩl } \\
\text { mașdar }\end{array}$ \\
\hline $\begin{array}{l}\text { ubatan } \\
\text { 'medicine' }\end{array}$ & “i.e., some components" (iaitu beberapa juzuk) & $\begin{array}{l}\text { ism } \\
\text { mașdar }\end{array}$ \\
\hline
\end{tabular}
kata kata 'words', corresponding to that between kalām 'speech' and kalima 'word' in Arabic linguistic theory. In the 'Ājurrūmiyya tradition, the four distinctive features of kalām are the following (Carter 1981: 8-10): it is a formal utterance (lafz), composite (murakkab), informative (mufid), and conventional (bi-l-wad'). This excludes, among other things, speech by someone sleeping, and self-evident statements of the type alsam $\bar{a}$ ' $u$ fawqanā 'the sky is above us' and al-'ardu tahtanā 'the earth is beneath us'. Two of these criteria are repeated almost verbatim by Raja Ali Haji, who defines perkataan as "an utterance that conveys useful information" (lafaz yang memberi faedah; ibid.: 38.26f.). He then gives the Malay translation of the two Arabic sentences quoted above, langit di atas kita and bumi di bawah kita, and declares that these fall outside the definition of speech (perkataan), because they do not convey new information. ${ }^{13}$ Arabic grammar. A sentence may begin with a noun serving as mubtada' (topic), on which a Habar (predicate) is 'made to lean', in other words, 'which supports a Habar' (ibid.: 39). The terms for the sentence constituents are introduced with their Arabic form, but also with a Malay translation, permulaan (mubtada'), berita (Habar); the verb bersandar 'to lean on'/disandarkan 'to be made to lean on' apparently reflects Arabic musnad/'isnād, which is not used in this text. ${ }^{14}$ As an example of a nominal sentence he cites zaydun qă 'imun 'Zayd is standing', which is translated as si zaid yang berdiri, where the relative sentence yang berdiri 'who is standing' translates Arabic

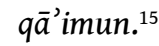

32 for instance, the restriction that the mubtada' cannot be an indefinite noun. Their 
dependence on the rules of Arabic grammar makes some of these restrictions difficult to understand when applied to Malay. One set of rules concerns the placement of the predicate, which in principle follows its topic. In some cases, this position is compulsory. Al-Širbīni (Nūr: 202-204) mentions three of them: i) when there might be confusion because both topic and predicate are definite, as in zaydun 'aHūka 'Zayd is your brother', unless the context makes clear which is the predicate, as in 'abū $y \bar{u} s u f a$ 'abū haniffata 'Abū Yūsuf is 'Abū Hanifa'; ii) when the topic might become confused with the agent, so that the nominal sentence turns into a verbal sentence, as in qāma zaydun 'Zayd stood up'; and iii) when the predicate is accompanied by 'illā or 'innamā.

All three cases are mentioned by Raja Ali Haji, even though they are hardly valid for Malay. For the first case, he mentions the sentence si zaid itu saudaramu 'Zayd is your friend' as an example of a sentence in which the predicate needs to be placed last. This restriction does not apply, he says, when the context indicates the predicate, as in 'abu yūsufa 'abū ḥanîfata "A 'A ū Yūsuf is 'Abū Ḥanīfa' (Bustān: 41.8f.).

The second restriction deals with the relationship between nominal and verbal sentences:

Don't say telah berdiri si zaid 'Zayd stood up'! If something like that is said, i.e. telah berdiri si zaid, it does not fall under the heading of topic/predicate, but under the heading of verb/agent (Maka jangan dikata telah berdiri si zaid, dan jika dikata juga seperti itu ya'ni telah berdiri si zaid, maka bukanlah pada bab mubtada' Habar ini, tetapi adalah ia pada bab fi'l dengan fā'il; ibid.: 20-23).

As for the third restriction, he simply states that in a sentence with hanya sungguhnya 'only' or melainkan 'except' the predicate always follows (ibid.: 41.31f.). The rather unnatural sounding example he cites for this restriction, tiada ada si zaid itu melainkan yang berdiri ia, probably means something like 'It is not the case that Zayd is [anything else] than that he is standing'.

The author also deals with the elision of the topic or the predicate (cf. Carter 1981: 204). One of the cases he mentions is that of the predicate after the Malay equivalent of lawla 'if it weren't for'. The example sentence in Malay, jikalau tiada si zaid binasalah si 'umar 'If it weren't for Zayd, 'Umar would be lost' (Bustān: 42.7), looks constructed. This particular case derives from the commentaries on the 'Alfiyya (v. 138), for instance by Ibn 'Aqīl (Šarḥ I: 248; see also ZamaHšsarī, Mufașșal: 14.6f.; Ibn Hišām, Qațr: 121).

Some of the rules are incomprehensible outside the context of Arabic grammar, for instance the rule that with a predicate consisting of a single word no pronoun is expressed. This is explained in the following passage, one of the few instances of an Arabic grammarian being mentioned by name:

39 In a Habar mufrad, such as si zaid saudaramu 'Zayd is your friend', the rule of the Habar is not to receive a pronoun, i.e. ia 'he'. But according to al-Kisā'i [d. 189/805] and alRummānī [d. 384/994], and a group of others, a pronoun must be understood here, as when you say si zaid saudaramu ya'ni ia 'Zayd is your friend', i.e. 'he' (adapun misal Habar yang mufrad itu 'si zaid saudaramu' adalah hukum Habar ini tiadalah diberi damir yakni 'ia'; akan tetapi pada Syeikh Kisa'i dan Syeikh Rumani dan beberapa jamā'ah, harus ditanggungkan damir, seperti katamu 'si zaid saudaramu' ya 'ni 'ia'; Bustān: 40).

40 The issue concerning the presence of a pronoun in a nominal sentence, which is irrelevant for Malay, derives from a well-known controversy in Arabic grammar (see Ibn al-'Anbārī, 'Inșâf: 30f.) about the question of whether a single noun as Habar in a 
sentence like 'amr g்lāmuka "Amr is your slave' contains a pronoun referring to the mubtada'. According to the Kufans (i.e. al-Kisā'ì) and al-Rummānī, this predicate contains a pronoun, since it is equivalent to a participle Hādimuka 'your servant [lit. your serving one]', which according to all grammarians contains a pronoun. This particular statement probably derives from the commentaries on the 'Alfiyya: Ibn 'Aqï (Šarh I: 205) mentions the opinion of al-Kisā'i wa-l-Rummānī wa-jamā' $a$, which is similar to the passage in the Bustān.

41 After the topic/predicate, our text discusses the agent ( $\left.f \bar{a}^{c} i l\right)$ and the verb $\left(f i^{\prime} l\right)$, which is the order of treatment in the 'Alfiyya, though not in the 'Ajjurrümiyya. ${ }^{16}$ Nothing much is said about this sentence type, but mention is made of the fact that the agent may be overt (zähir) or hidden (tersembunyi); the latter term translates Arabic mudmar. This is

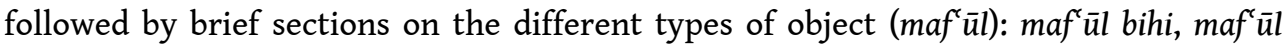
muțlaq, maf'ūl lahu, maf' ül fihi, and maf' ūl ma'ahu, followed by other accusative constructions, $h \bar{a} l$, tamyiz. In general, the order of treatment of these sections follows that of the 'Ajjurrūmiyya in putting the direct object first, followed by the maf' $\bar{u} l$ muțlaq, whereas the 'Alfiyya tradition starts with the verbal noun. Note that our author uses maf' $\bar{u} l$ muțlaq instead of mașdar; the latter is the term used by Ibn 'Ājurrūm, for which he is criticized by al-Širbīnī (Carter 1981: 344; cf. Kasher 2019: 206). Raja Ali Haji also uses maf' ül fihi where the 'Ājurrümiyya has zarf; this is mentioned as an alternative term by the commentators ('Azharī, Šarh: 100.6; Kafrāwī, Šarh: 261.5; Širbīnī, Nūr: 352).

In the 'Ājurrümiyya tradition, the next sections deal with the tawābi', satellite constituents that derive their case ending from the word they follow, i.e. attribute $\left(n a^{\prime} t\right)$, corroboration ( $\left.t a^{\prime} k i d\right)$, coordination ('at $f$ ), and apposition (badal). The author of the Bustān leaves out coordination and deals with the adjective (sifa) at the end. Concerning $t a^{\prime} k i d$, he repeats almost literally the explanation in Dahlān's commentary (Šarh: 428-429; absent in al-Širbīnī): corroboration is needed to discard any ambiguity. When you say 'Zayd came', someone might assume that a letter or a messenger from him has arrived, but this possibility vanishes when you add nafsuhu/dirinya 'himself' (Bustān: 45).

The section on badal (ibid.: 45f.) follows the 'Ājurrūmiyya and its commentaries (Širbīnī, Nūr: 312ff., 318-320) closely. Four kinds of substitution are mentioned:

i. badal al-kull min al-kull: this is not the term used in the 'Ājurrümiyya, which has badal al-šay' min al-šay':17 lalu aku dengan saudara engkau si zaid 'I passed your friend, Zayd', Arabic $j \bar{a}$ ’a zaydun 'aHūka 'Zayd came, your brother'.

ii. badal al-ba'd min al-kull: makan aku roti sepertiganya 'I ate the bread, one third of it', Arabic 'akaltu l-ragifa tultahu.

iii. badal al-ištimāl: telah mencengangkan daku si zaid ilmunya 'I was amazed by Zayd, by his knowledge', Arabic 'a 'jabanī zaydun 'ilmuhu.

iv. badal al-gálaț: aku lihat akan laki akan himār 'I saw a man, a donkey', Arabic ra'aytu zaydan alfarasa 'I saw Zayd, the horse'.

The section on șifa (Bustān: 46) contains a succinct description of the adjective's function, not found in the commentaries on the 'Ājurrūmiyya. According to Raja Ali Haji, the adjective has five different roles: it serves to specify (taHsisis), to praise, to blame, to express commiseration, and to confirm. This last role is illustrated with $Q$. 69/13 "and when the trump will be blown once" (fa-'id wāhidatun), translated into Malay as maka apabila ditiuplah pada sangkakala dengan tiup yang satu..$^{18}$ Presumably, Raja Ali Haji has taken over from an Arabic commentary a 
remark about wāhidatun emphasizing the singular of the masdar and applied it to the Malay translation, where the numeral does not have this function.

What follows in the 'Ājurrümiyya is the chapter about genitive constructions ( $m a$ a fü $\bar{u} \bar{a} t$ ), for which there is no direct parallel in Malay grammar. The point picked up by Raja Ali Haji in the last of the grammatical sections of the Bustān is that of the 'id̄âfa (Bustān: 47). This part is similar to that in the 'Ājurrūmiyya (Carter 1981: 456-458) and has the same division of the genitive construction into two types, one with the meaning of li- and one with the meaning of min, in Malay bagi and daripada, respectively. Even the examples are partly the same, for the first type budak si zaid 'Zayd's servant', as equivalent of gulämu zaydin, and for the second type cincin perak 'a silver ring' and kain sutera 'a silk cloth', as (partial) equivalents of thātamu hadìdin 'an iron ring' and țawbu Hazzin 'a silk cloth'. Raja Ali Haji adds a third type, absent from the 'Ājurrūmiyya, namely the genitive with the meaning of $f_{i}$ (pada), for which he gives the Malay example pukul hari itu, translating the Arabic darbu l-yawmi 'today's hitting' that is mentioned as an example for this type of genitive construction in Ibn al-Hājib's Käfiya (p. 108). ${ }^{19}$

The author further remarks that there are two possible constructions of the 'idāfa, one with a definite noun and one with an indefinite noun as the second constituent. This mirrors a remark in al-Širbinī's commentary (Nür: 460), that the former is used for purposes of ta' riff, the latter for purposes of taHșiș. The two constructions are explained in the Malay text as faedah kepada pengenalan '[conveying] the meaning of making known' for the former, and faedah kepada menentukan '[conveying] the meaning of determining' for the latter. These two phrases are offered as a translation of the Arabic terms ma'rifa and nakira, but it is doubtful they could be understood by an average Malay reader without knowledge of Arabic grammar.

\section{Conclusion}

In compiling his grammar of Malay, Raja Ali Haji followed the model of the grammatical literature in which he was raised. It is hard to ascertain exactly which treatises were his main authority, but it seems that he mostly followed the 'Ájurrūmiyya tradition, although he borrowed rules and remarks from other commentaries as well. In a fair number of cases, the grammatical rules and examples cited in the Bustān are irrelevant for the structure of Malay. His desire to find Malay analogues for Arabic constructions is evident, even to the point where he constructs Malay sentences rather than deriving them from living speech. The Malay practice of learning Arabic texts by heart together with a Malay translation may have increased the acceptability of "translationese", and may even have led to the introduction of new constructions into the language in much the same way as European languages introduced constructions taken over by Latin, often on the basis of Bible translations from Latin or Hebrew.

With respect to lexicography, Raja Ali Haji himself noted the difference between his own approach and that of the Western scholars with whom he was in contact, as van der Putten (1995) reports. Presumably, he felt that his own discursive approach was more in line with the Arabic dictionaries, which he believed to be better suited to the Islamic language that was Malay. 
Since Raja Ali Haji was a pioneer in writing about Malay grammar in Malay, the creation of a technical lexicon must in large part be attributed to him, although some Malay terminology in Qur'ānic exegesis and Arabic grammar was available. He provides Malay equivalents for a considerable number of Arabic grammatical terms in the form of loan translations, and in some cases even replaces an Arabic term with a Malay one, for instance in the 'isnād terminology. As the text is written in Jawi, it is not always possible to see whether an Arabic term is used in the original form or as an integrated loanword. The written word lafz, for instance, was probably pronounced lafaz, and fi'l was pronounced fi'il. The integration of Arabic loanwords is evident in a number of derivations, such as disifatkan 'to be described' (Bustān: 42.25) or dikhabarkan 'to be predicated' (ibid.: 32.13 ). ${ }^{20}$

Raja Ali Haji's work remained a relatively isolated attempt at describing Malay within an Arabic framework. Even though he is still revered as a hero of the Malay language, ${ }^{21}$ modern grammars follow a different framework, that of Western linguistics, as in Moeliono and Dardjowidjojo's (1988) standard grammar, which has traces of Arabic grammatical terminology, but almost always opts for the Western terminology.

\section{BIBLIOGRAPHY}

\section{Primary sources}

'Azharī, Šarh = Zayn al-Dīn Hālid ibn 'Abdallāh al-'Azharī. Šarh al-muqaddima al-'ājurrūmiyya fì 'ușūl 'ilm al- 'arabiyya li-l-țullāb wa-l-mubtadi' iña. Ed. by Maḥmūd Nașșār. Beirut: Dār al-Kutub al'Ilmiyya. 2013.

Daḥlān, Šarh = 'Aḥmad ibn Zaynī Daḥlān. Šarh al-'Ājurrūmiyya. Ed. with marginal comm. Tašwīq alHillān by Muhammad Ma'ṣūm ibn Sālim al-Samarānī al-Safātūnī. Beirut: Dār al-Kutub al-'Ilmiyya. 2013.

Elias, Majālis = Elias of Nisibis, Kitāb al-majālis. Ed. with Russian transl. by N.N. Seleznjov. Moscow: Grifon. 2018.

Ibn al-'Anbārī, 'Inșāf = 'Abū l-Barakāt 'Abd al-Raḥmān ibn Muḥammad Ibn al-'Anbārī. Kitāb al'inșāff fì masā' il al-Hilāf bayna l-naḥwiyyīn al-Bașriyyīn wa-l-Kūfiyyīn. Ed. by G. Weil. Leiden: E.J. Brill. 1913.

Ibn 'Aqīl, Šarḥ = Bahā' al-Dīn 'Abdallāh Ibn 'Aqīl. Šarḥ al-'Alfiyya. Ed. by Muhammad Muhyī l-Dīn 'Abd al-Hamīd. 14th ed. 2 vols. Beirut: Dār al-Fikr. 1972.

Ibn al-Ḥājib, Kāfiya = Jamāl al-Dīn 'Abū 'Amr 'Uțmān ibn 'Umar Ibn al-Ḥājib. Al-Kāfiya fì l-naḥw ma'šarhihi al-Nājiya. Karachi: Maktabat al-Madīna. 2012.

Ibn Hišām, Qațr = Jamāl al-Dīn 'Abū Muḥammad 'Abdallāh ibn Yūsuf Ibn Hišām al-' Anșārī. Šarh Qațr al-nadā wa-ball al-șadā. Ed. by 'Imīl Badī' Ya'qūb. 8th ed. Beirut: Dār al-Kutub al-'Ilmiyya. 2018.

Histoire Épistémologie Langage, 42-1 | 2020 
Kafrāwī, Šarh = Ḥasan ibn 'Alī al-Kafrāwī. Šarh matn al-'Ājurrūmiyya. Ed. by Māzin bin Sālim Bā Wazīr. Riyadh: Dār Ṭayya. 1418 AH.

Raja Ali Haji, Bustān = Raja Ali Haji. Bustān al-kātibīn li-l-șibyān al-muta'allimīn, lithograph. Pulau Penyengat (Riau). [1851] (repr. Singapore. 1310/1892; transl. into Dutch by Ph.S. van Ronkel (1901); ed. (in transcription) by Hashim bin Musa. Kuala Lumpur. Yayasan Karyawan. 2005.

Raja Ali Haji, Pengetahuan = Raja Ali Haji. Kitab pengetahuan bahasa. Ed. (in transcription) by H. bin Musa. Kuala Lumpur: Yayasan Karyawan. 2010.

Širbīnī, Nūr = Muhammad ibn Muḥammad al-Širbīnī. Nūr al-sajiyya fì ḥall 'alfāz al-' Ājurrūmiyya. Ed. and transl. by M.G. Carter. 1981.

ZamaHš̌arī, Mufașṣal = 'Abū l-Qāsim Maḥmūd ibn 'Umar al-ZamaHš̌arī. Kitāb al-mufașṣal fī l-naḥw. Ed. by J.P. Broch. Christiania: Libraria P.T. Mallingii. 1879.

\section{Secondary sources}

Bertaina, D. 2011. Science, syntax, and superiority in eleventh-century Christian-Muslim discussion: Elias of Nisibis on the Arabic and Syriac languages. Islam and Christian-Muslim relations 22/2: 197-207.

Boogert, N. van den. 1997. The Berber literary tradition of the Sous. With an edition and translation of "The Ocean of Tears" by Muhammad Awzal (d.1749). Publication of the De Goeje Fund 27. Leiden: Nederlands Instituut voor het Nabije Oosten.

Bruinessen, M. van. 1990. Kitab kuning: Books in Arabic script used in the Pesantren milieu. Comments on a new collection in the KITLV library. Bijdragen tot de Taal-, Land-en Volkenkunde 146: 226-269.

Carter, M.G., ed. 1981. Arab linguistics: An introductory classical text with translation and notes. Amsterdam studies in the theory and history of linguistic science. Series 3, Studies in the history of linguistics 24. Amsterdam: J. Benjamins.

Eickelman, D.F. 1978. The art of memory. Islamic education and its social reproduction. Comparative studies in society and history 20: 485-516.

Ermers, R. 1999. Arabic grammars of Turkic. The Arabic linguistic model applied to foreign languages \& Translation of 'Abū Hayyān al-'Andalusī's Kitāb al-'idrāk li-lisān al-'atrāk. Studies in Semitic languages and linguistics 28. Leiden/Boston/Cologne: Brill.

Grotans, A.A. 2006. Reading in Medieval St. Gall. Cambridge studies in palaeography and codicology 13. Cambridge: Cambridge University Press.

Hamel, R.E. 2005. Language empires, linguistic imperialism, and the future of global languages [http://www.hamel.com.mx/Archivos-PDF/Work\%20in\%20Progress/ 2005\%20Language\%20Empires.pdf].

Hidayatullah, M.S. 2012. Bustān al-kātibīn: Pengaruh tata bahasa Arab dalam tata bahasa Melayu [Bustān al-kātibīn: The influence of Arabic grammar in Malay grammar]. Manuskripta 2/1: 53-77.

Jeremiás, É.M. 1997. Zā id and aṣl in early Persian prosody. Jerusalem studies in Arabic and Islam, no. 21: 167-186.

Kaptein, N. 2000. Arabic influence on Malay linguistics. In History of the language sciences: An international handbook on the evolution of the study of language from the beginnings to the present, ed. 
by S. Auroux, E.F.K. Koerner, H.-J. Niederehe, and K. Versteegh, vol. 1, 333-336. Handbücher zur Sprach- und Kommunikationswissenschaft 18/1. Berlin/New York: W. de Gruyter.

Kasher, A. 2019. How to parse effective objects according to Arab grammarians? A dissenting opinion on al-maf ül al-muțlaq. In The foundations of Arabic linguistics, IV, The evolution of theory, ed. by M.E.B. Giolfo and K. Versteegh, 198-211. Studies in Semitic languages and linguistics 97. Leiden: Brill.

Kridalaksana, H. 1991. Bustanulkatibin dan Kitab pengetahuan bahasa: Sumbangan Raja Ali Haji dalam ilmu bahasa Melayu [The Bustanulkatibin and the Kitab pengetahuan bahasa: Raja Ali Haji's contribution to Malay linguistics]. In Masa lampau bahasa Indonesia: sebuah bunga rampai, ed. by H. Kridalaksana, 349-361. Seri ILDEP 43. Yogyakarta: Penerbit Kanisius.

Moeliono, A.M. and Dardjowidjojo, S., eds. 1988. Tata bahasa baku bahasa Indonesia [A standard grammar of Indonesian]. Jakarta: Departemen Pendidikan dan Kebudayaan.

Mustari. 1998. Raja Ali Haji dan pemikiran kebahasaannya: Studi terhadap Kitāb bustān al-kātibīn li as-subyān al-muta allimīn [Raja Ali Haji and his linguistic thinking: a study of the Kitāb bustān al-kātibīn li as-subyān al-muta allimīn]. Al-Jāmíah 61: 181-198.

Ostler, N. 2005. Empires of the word. A language history of the world. New York: HarperCollins Publishers.

Poppe, E. 1999. Latinate terminology in Auraicept na nÉces. In History of linguistics 1996. Selected papers from the seventh international conference on the history of the languages sciences (ICHOLS VII), Oxford, 12-17 September 1996, I,Traditions in linguistics worldwide, ed. by D. Cram, A.R. Linn, and E. Nowak, 191-201. Amsterdam studies in the theory and history of linguistic science. Series III, Studies in the history of the language sciences 94. Amsterdam/Philadelphia PA: J. Benjamins.

Putten, J. van der. 1995. Taalvorsers en hun informanten in Indië in de $19^{\mathrm{e}}$ eeuw. Von de Wall als politiek agent in Riau? [Language experts and their informants in the Indies in the 19th century: Von de Wall as political agent in Riau?]. Bijdragen tot de Taal-, Land-en Volkenkunde 151: 44-75.

Putten, J. van der. 2002. On sex, drugs and good manners: Raja Ali Haji as lexicographer. Journal of Southeast Asian studies 33: 415-430.

Riddell, P.G. 1990. Transferring a tradition: 'Abd al-Ra' ūf Al-Singkilì's rendering into Malay of the Jalālayn commentary. Monograph Series - Center for South and Southeast Asian Studies 31. Berkeley CA: University of California.

Riddell, P.G. 2002. Literal translation, sacred scripture and Kitab Malay. Studia islamika: Indonesian journal for Islamic studies 9: 1-26.

Riddell, P.G. 2017. Malay court religion, culture and language: Interpreting the Qur'ān in 17th century Aceh. Texts and studies on the Qur'ān 12. Leiden: Brill.

Ronkel, P.S. van. 1901. De Maleische schriftleer en spraakkunst getiteld Boestānoe'l kātibīna [The Malay primer of script and grammar, entitled Boestānoe'l kātibīna]. Tijdschrift voor Indische Taal-, Land-en Volkenkunde 44: 512-581.

Sidarus, A. 2010. La Renaissance copte arabe au Moyen Âge. In The Syriac Renaissance, ed. by H. Teule, C. Fotescu Tauwinkel, B. ter Haar Romeny, and J. van Ginkel, 311-340. Eastern Christian Studies 9. Leuven/Paris/Walpole: Peeters.

Versteegh, K. 2019. Grammars of Malay between Arab and Western model. In The foundations of Arabic linguistics, IV, The evolution of theory, ed. by M.E.B. Giolfo and K. Versteegh, 295-318. Studies in Semitic languages and linguistics 97. Leiden: Brill. 
Waquet, Fr. 1998. Le latin ou L'empire d'un signe, $\mathrm{XVI}^{e}-\mathrm{XX}{ }^{e}$ siècle. L'Évolution de l'humanité. Paris: Albin Michel.

\section{NOTES}

1. I wish to thank David Bertaina (University of Illinois Springfield) for kindly sending me a copy of his article on Elias of Nisibis, and Jan van der Putten (Universität Hamburg) for his help in obtaining some of the Indonesian material. Thanks are also due to an anonymous reviewer for some corrections and a useful reference to the Kăfiya as a possible source.

2. See Kridalaksana (1991); Kaptein (2000); Hidayatullah (2012); Mustari (1998). In quotations from the Bustān, I use, with slight changes in the transliteration of the Arabic words, the transliterated edition by Hashim bin Musa (2005), which also contains a facsimile of the Leiden ms. Kl 107. The manuscript used by van Ronkel (1901) for his Dutch translation of the text, Leiden no. 218, is identical to the lithograph edition of Pulau Penyengat (Riau) [1851], but it has one additional paragraph about separate writing of words and one about 'i'rāb; both are missing in the other manuscripts (see van Ronkel (1901): 533 \& 550).

3. In the East Indies, the most popular commentaries on the 'Ájurrümiyya were those by al'Azharī (d. 905/1499), al-Kafrāwī (d. 1207/1787), and 'Aḥmad ibn Zaynī Daḥlān (d. 1304/1886), a contemporary Meccan scholar (van Bruinessen 1990). I do not know whether al-Širbīnì's (d. 977/1569) extensive commentary Nūr al-sajiyya was used in Southeast Asia. An important commentary on the 'Alfiyya is that by Ibn 'Aqil (d. 769/1367). Another popular treatise was Qațr al-nadā wa-ball al-ṣadā with autocommentary by Ibn Hišām (d. 761/1360).

4. This definition is almost identical with the one in the 'Ājurrūmiyya (Carter 1981: 34), which has tag̀yīr 'aḥwāl 'awāHir al-kalām.

5. The discussion is complicated by Raja Ali Haji's use of technical terms, for instance when he states that it is sometimes obligatory "to use 'i'rāb with a letter" (wajib dii'rabkan dengan huruf; Bustān: 23.21) in cases like kumbang 'bumblebee' <kwmby> and kambing 'goat' <kmbyy>. He seems to suggest that there are two ways of indicating vowels (mengi'rabkan), with baris and with huruf, but the text is not very clear.

6. It is not clear to me why dikhabarkannya 'to be predicated by it' is used here; presumably, he means that the particle is the operator of the majrür.

7. As an example, the author refers to the famous issue of 'akaltu l-samaka hattā $r a$ 's-i/a/u-hu 'I ate the fish without/with/with its head', but without quoting the Arabic sentence (Bustān: 33; van Ronkel 1901: 551). Here, too, the problem of ambiguity exists in both languages, but they have different tools to solve them: while Arabic has declensional endings, Malay uses particles (Versteegh 2019).

8. This expression refers to the description right at the beginning of Sïbawayhi's Kitāb where the term harf is specified as harf $j \bar{a}^{\prime} a$ li-ma 'na 'particle that brings a meaning', presumably in order to distinguish it from harf in the sense of 'letter'.

9. In the 'Ájurrūmiyya, this is dealt with in the chapter on the na't.

10. The later commentaries (Kafrāwī, Šarh: 209; Širbīnī, Nūr: 266) take Ibn 'Ājurrūm to task for having omitted the relatives.

11. Elsewhere Raja Ali Haji uses ism fi'l in the sense of 'interjection' (Bustān: 28).

12. In the case of melainkan 'except', a distinction is made between the positive and the negative exception. In Arabic, this distinction has a function since it determines the case ending in the excepted noun after 'illā, whereas in Malay it does not.

13. According to al-Kafrāwī ( ̌̌arh, p. 13) 'conventional' (bi-l-waḍ') excludes foreign languages from the definition of "speech", so this is not the most appropriate criterion to be used in a 
grammar of Malay. The shorter form of the definition in the Bustān corresponds to the one in Ibn Hišām (Qațr: 54) "speech is a meaningful utterance" (al-kalām lafẓ mufid).

14. Note that bersandar and disandarkan are also used as translation for 'idāfa (Bustān: 47.2).

15. For the interpretation of berdiri as a relative sentence, see above.

16. In his commentary on the 'Ājurrūmiyya, al-Širbīnī (Nūr: 150ff.) mentions the alternative sequence of starting with the topic, which he attributes to Ibn Mālik and Ibn Hišām.

17. Al-Širbinī mentions the former, but states that it is less appropriate; it is mentioned as an alternative name by Daḥlān (Šarh: 437.1) and al-Kafrāwī (Šarh: 232.15). Ibn Hišām (Qațr: 288) has badal kull min kull.

18. These categories of adjectives are mentioned by al-ZamaHš̌arī (Mufașsal: 46), who also quotes the Qur'ānic verse as an example of an adjective used for the purpose of ta'kid. The same categories are distinguished by Ibn Hišām (Qaț: 267), who cites the same example for the function of ta'kìd and adds a sixth function, that of clarification (tawdịh). Ibn al-Ḥājib (Käfiya: 115f.) leaves out commiseration, replacing it with tawdih.

19. The third type is mentioned also by some of the commentators on the 'Ajjurrümiyya ('Azharī, Šarh: 125; Širbīnī, Nūr: 458-460; Kafrāwī, Šarh: 313), who attribute it to Ibn Mālik, but without quoting any example. It is mentioned indeed in the commentaries on Ibn Mālik's 'Alfiyya (v. 386), for instance by Ibn 'Aqīl (Šarh II: 43), and by Ibn Hišām (Qațr: 237). The 'Alfiyya tradition discusses the 'id̄afa construction before the satellite constructions, rather than after them.

20. The number of derivates is relatively low compared to the general lexicon and the specialized lexicon of Qur'ānic exegesis (Riddell 1990: 245-250), possibly because Raja Ali Haji seems to prefer loan translations over loanwords.

21. A memorial sign in Tanjung Pinang on the island of Riau calls him "The father of Malay/ Indonesian, an intellectual of the beginning of the twentieth century" (Bapak bahasa MelayuIndonesia budayawan di gerbang abad XX); see e.g. http://liputankepri.com/catatan-sejarah-pulaupenyengat-tanjungpinang (downloaded 30.07.2018).

\section{ABSTRACTS}

Throughout history, a number of languages have achieved the status of learned language, i.e., a language included in the curriculum of an educational system without yielding any communicational benefits. In large parts of the Islamic world, Arabic was (and still is) such a learned language. Acquisition of the learned language took place through the memorization of texts, with instruction and/or translation in vernacular languages. The vernacular languages themselves were not deemed to be in need of grammatical description, which explains why grammars for them were late to be developed. The present paper focuses on Malay, the lingua franca of choice in Southeast Asia for both Muslim missionaries and British and Dutch colonial administrators, while serving as the auxiliary language in the Islamic curriculum. The first grammars of Malay were published by the British and Dutch. Malay grammars written by native speakers did not make their appearance until the nineteenth century. Their main representative is Raja Ali Haji (d. probably 1873). In his Bustān al-kātibīn, he used the grammatical framework of Arabic grammar for a grammatical sketch of Malay, using in part the Malay terminology that had been developed in traditional education for the study of Arabic grammar and Qur'ānic exegesis. 
À travers les siècles certaines langues ont fonctionné comme des langues savantes, c'est-à-dire des langues enseignées dans les écoles pour leur valeur culturelle intrinsèque, mais sans pour autant constituer une langue de communication. Dans le monde islamique, l'arabe a longtemps servi comme langue savante, dont l'acquisition se faisait sous la forme de mémorisation de textes joints à leur traduction dans la langue vernaculaire, qui servait comme langue d'instruction dans les écoles. Dans le présent article, nous prenons comme point de départ la position de l'arabe en Asie du Sud-Est, où le malais, tout en fonctionnant comme langue d'instruction dans les écoles, fut choisi par l'administration coloniale comme langue intermédiaire dans sa communication avec la population indigène. Par conséquent, ce furent les Anglais et les Néerlandais qui publièrent les premières grammaires de cette langue vernaculaire, composées dans le cadre de la linguistique européenne. Les premières descriptions du malais fondées sur un modèle linguistique arabe n'apparurent qu'à la fin du XIX siècle. Le représentant principal de cette tradition linguistique est Raja Ali Haji (m. probablement en 1873). Dans son traité Bustān alkātibin, il emprunta le modèle de la tradition grammaticale arabe afin de composer une esquisse de la structure du malais, dans laquelle il se servait en partie de la terminologie grammaticale malaise qui avait été développée dans le système scolaire traditionnel pour l'étude de la grammaire arabe et l'exégèse coranique.

\section{INDEX}

Keywords: 'Ājurrūmiyya, Arabic grammatical tradition, extended grammar, grammar, Indonesia, learned language, loan translation, loanwords, Malay, Malaysia, Raja Ali Haji, terminology

Mots-clés: 'Ājurrūmiyya, calque, emprunt lexical, grammaire, grammaire étendue, Indonésie, langue savante, malais, Malaisie, Raja Ali Haji, terminologie, tradition grammaticale arabe

\section{AUTHOR}

\section{KEES VERSTEEGH}

Radboud Universiteit, Nijmegen, The Netherlands 